Литвин В.В., Таран I.O.

Начіональний технічний університет «Дніпровська політехніка», м. Дніпро, Украйна

\title{
КІЛЬКІСНА ОЦІНКА ВПЛИВУ ОБЛАШТУВАННЯ ПАРКУВАЛЬНИХ МІСЦЬ У КРАЙНІЙ ПРАВІЙ СМУЗІ НА ЕФЕКТИВНІСТЬ ДОРОЖНЬОГО РУХУ
}

\begin{abstract}
Стрімкі темпи росту автомобілізації призвели до значного перевищення попиту на місця паркування над наданою їх кількістю. Подібна ситуація є характерною рисою більшості середніх та великих міст України. В умовах недоліку місць для паркування найбільшого поширення набуло облаштування паркувальних місць у крайній правій смузі. Застосування даного заходу призводить до зниження пропускної спроможності вуличнодорожньої мережі міста та погіршення умов безпеки руху транспорту. Тому, у роботі проаналізовано вплив облаштування таких паркувальних місць на ефективність руху у м. Дніпро. В якості об'єкта дослідження обрано перехрестя вул. Я. Мудрого та вул. Воскресєнської. Інтенсивності транспортних потоків на перехресті були отримані методом натурних обстежень для ранкової години «пік» $37^{00}$ до $8^{00}$. У програмному середовищі PTV VISSIM розроблено дві імітаційні транспортні моделі перехрестя (без смуги та зі смугою для паркування). Результати моделювання, засвідчують, що облаштування паркувальних місць у крайній правій смузі знижує ефективності руху за всіма обраними показниками в діапазоні від $26 \%$ до $62 \%$. Значення запропонованого авторами комплексного показника ефективності для дороги без «парковки» становить - 1,00, а для дороги з облаштованою паркувальною зоною - 0,54. Доведено, що загальна ефективність такого рішення для обраного об’єкту дослідження знизила ефективність організації дорожнього руху на 46\%. Проведено експертне оцінювання, за результатами якого були розраховані вагові коефіцієнти для обраних показників. Отриманий розподіл вагових коефіцієнтів характеризується дуже незначною розбіжністю. Це засвідчує, що всі обрані авторами показники $\epsilon$ значимими під час прийняття остаточних рішень щодо обгрунтування заходів 3 підвищення ефективності дорожнього руху.

Ключові слова: вулично-дорожня мережа, смуга руху, перехрестя, імітаційне моделювання, довжина затору, вагові коефіцієнти, час затримки, дорожний рух, PTV VISSIM.
\end{abstract}

\section{ВСТУП}

В сучасних умовах із стрімким збільшенням рівня автомобілізації у із кожним роком все гостріше постає проблема недостатньої кількості паркувальних місць особливо у великих та середніх містах України [1]. Внаслідок цього спостерігається стихійне будівництво паркувальних майданчиків майже на всій території міст зазвичай із значними порушеннями діючих вимог, правил, норм та стандартів при обладнанні паркувальних об'єктів технічними засобами регулювання дорожнього руху та дорожньою розміткою. Порушення правил паркування створює перешкоди вільному пересуванню автомобілів та пішоходів, негативно впливає на ступінь аварійності на дорогах і значною мірою сприяє виникненню заторів, погіршуючи безперебійну організацію руху на території міста.

Незважаючи на підвищення активності при створенні паркувального простору, багато теоретичних та прикладних задач побудови, функціонування та оцінки ефективності управління парковками на сьогоднішній момент і досі не вирішено. 3 позицій системного підходу розглядати задачу управління парковками необхідно у взаємозв'язку з організацією дорожнього руху 3 урахуванням обмежень в рамках транспортного планування для знаходження балансу між суперечливими цілями всіх учасників руху. В умовах недоліку місць для паркування (особливо у центральній частині міста) найбільшого поширення набуло облаштування паркувальних місць у крайній правій смузі. Застосування даного заходу породжує ряд гострих проблем: зниження пропускної спроможності вулично-дорожньої мережі міста, погіршення умов безпеки руху транспорту, ускладнення проїзду громадського транспорту та екстрених служб, труднощі під час проведення механізованого прибирання вулиць, тощо.

Слід також зазначити, що в сучасних умовах для пошуку ефективних стратегій з проектування вулично-дорожньої мережі та організації дорожнього руху необхідно враховувати широкий спектр характеристик транспортного потоку та закономірності впливу зовнішніх і внутрішніх факторів. Тому одним із найефективніших методів обгрунтування проектних рішень щодо вдосконалення організації дорожнього руху у великих містах $є$ використання сучасних пакетів транспортного імітаційного моделювання [2].

\section{АНАЛІЗ ЛІТЕРАТУРНИХ ДАНИХ ТА ПОСТАНОВКА ПРОБЛЕМИ}

Автостоянки - спеціально обладнані майданчики на території міста для зберігання автомобілів. Автостоянки поділяють за тривалістю знаходження на них автомобілів і способом зберігання. За тривалістю зберігання автостоянки поділяються на декілька типів [3]: 
- для постійного збереження - більше 1 доби, їх розміщують біля житлових будинків та міжрайонних територіях;

- для великого терміну збереження - 8 годин, їх розміщують біля підприємств та установ;

- для середнього терміну збереження - 2-4 години, їх розміщують біля будинків і споруд, що періодично збирають велику кількість людей (стадіони, театри, торгівельно-розважальні комплекси); ринків.

- для короткочасного терміну збереження - до 2 годин, їх розміщують біля вокзалів та

Автостоянки можуть бути відкритими і закритими [4].

Також автостоянки поділяються на позавуличні і вуличні [1]. Позавуличні - це спеціально облаштовані майданчики на території міста, які розташовані поза межами вулично-дорожньої мережі (ВДМ). Вуличні стоянки передбачають використання існуючої ВДМ для розміщення авто та відповідно знижують пропускну здатність вулиць.

По способу постановки автомобілів на стоянку відносно осі вулиці вуличні стоянки прийнято ділити на:

- $\quad 3$ паралельним способом постановки (рисунок $1 \mathrm{a}$ );

- під кутом $30^{\circ} ; 45^{\circ}$ або $60^{\circ}$ (рисунок 1 б-г);

- 3 перпендикулярним способом постановки (рисунок 1 д).

При збільшенні кута постановки автомобіля збільшується місткість стоянки, але при цьому збільшується ширина стоянки та підвищується час необхідний для в 'їзду-виїзду на стоянку.

Вуличні стоянки можуть бути організовані:

- на смузі руху (на проїзній частині вулиці вздовж бордюру або під кутом к бордюру);

- на тротуарі;

- в «кишені» (місцеве розширення проїзної частини за рахунок зеленої смуги або тротуару); ширина «кишені» залежить від прийнятої схеми постановки автомобілів на стоянку;

- на центральній розділювальній смузі завширшки не менш 5,5 м або на напрямному острівці;

- змішані.

Вирішенню проблеми розробки раціональних схем організації паркувального простору у великих містах присвячені чисельні наукові роботи як вітчизняних [5-8] так і іноземних науковців [914].

Автором роботи [5] розглянуто закордонний досвід організації парковок у містах. Досліджено деякі питання впливу організації парковок на безпеку руху. Наведені теоретичні дослідження по обгрунтуванню розміщення паркувальних місць в окремих районах м. Харків.

У статті [6] описані основні проблеми, які виникають при збільшенні рівня автомобілізації населення. Проаналізовано розподіл часу на рух і стоянку автомобілів у місті, проблему використання паркомісця одним автомобілем. Наведено класифікацію паркування в залежності від часу перебування автомобілів на парковці, загальні вимоги до розміщення і планування стоянок. Аргументовано доцільність влаштування паркувальних зон під вулицями міста. Вказані основні переваги і недоліки використання підземного простору, зокрема під вулицями міста.

В результаті виконаних досліджень [7] запропоновано конструкцію компактної механізованої автостоянки із зберіганням автомобілів на спеціальних піддонах, покладених у багатоярусний стелаж за допомогою автонавантажувача і поворотного круга.

У статті [8] розглядається методика побудови просторово-точної імітаційної моделі організації паркінгу автомобілів в центральній частині великого міста, на прикладі м. Харкова. Модель організації паркінгу заснована на моделюванні поведінки кожного водія, який бере участь у процесі паркування свого автомобіля і охоплює основні етапи паркування: рух до місця призначення, пошук i покидання паркувального машиномісця. Розглянуто структуру моделі, iii основні алгоритми. Розроблена модель дозволяє визначати вплив різних просторових сценаріїв на організацію парковок на території міста.

Результатів досліджень [5-14] свідчить, що на сьогоднішній день існує достатня кількість планувальних та технологічних рішень, які дозволяють успішно вирішувати проблему недоліку місць для паркування легкового автотранспорту навіть в умовах щільної забудови міста. 


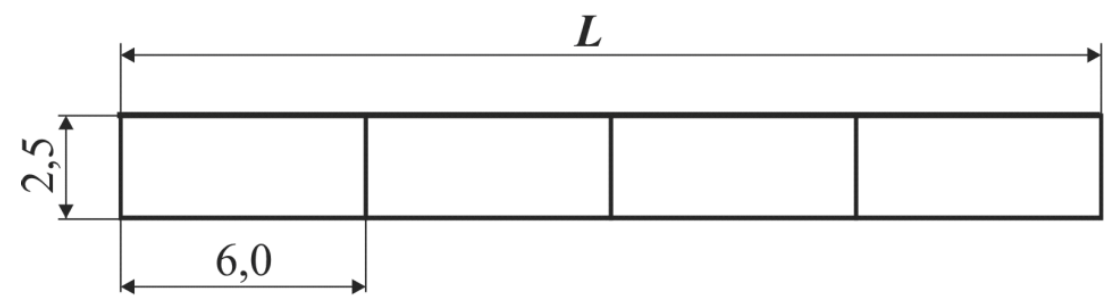

$N_{a b m}=\frac{\mathrm{L}}{6}$

(1)

a) паралельно осі вулиці

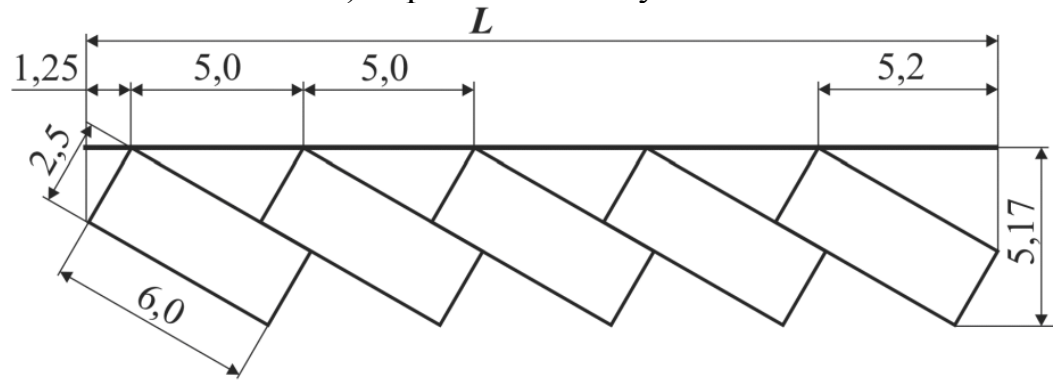

б) під кутом $30^{\circ}$

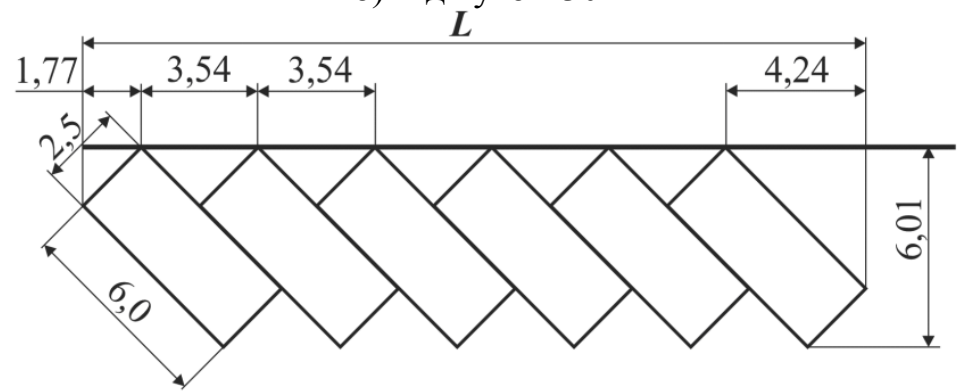

в) під кутом $45^{\circ}$

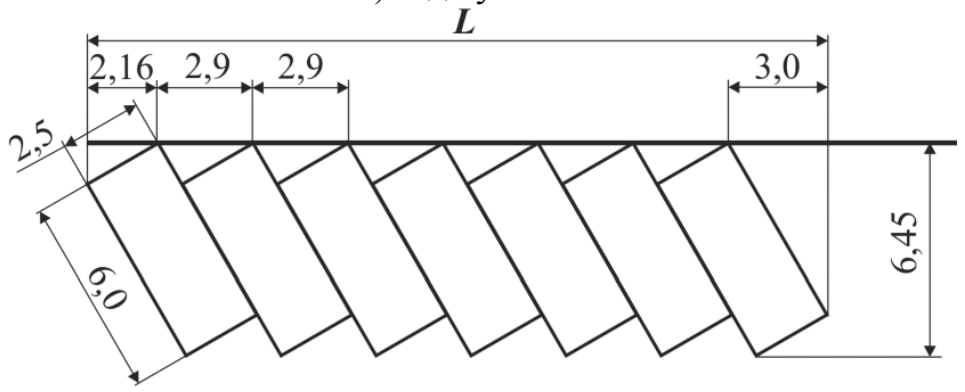

г) під кутом $60^{\circ}$

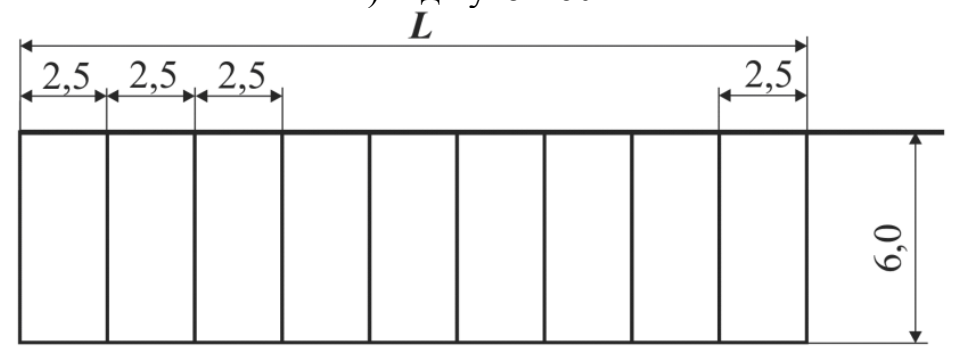

д) під кутом $90^{\circ}$

Рисунок 1 - Планувальні рішення вуличних стоянок [3]

Але аналіз стану існуючої системи паркування транспортних засобів в Україні показує, що організаційні, нормативно-правові та фінансові умови функціонування зазначеної системи не відповідають потребам населення та європейським стандартам, а також не в змозі забезпечити належний розвиток паркувального простору. Виконаний авторами аналіз стану сучасної паркувальної системи у м. Дніпро, дозволив виділити наступні найбільш актуальні ії проблеми:

- невідповідність інфраструктури паркування сучасним вимогам;

- недостатня кількість паркувальних місць на відведених, спеціально обладнаних майданчиках для паркування та паркінгів; 
- низька якість послуг з паркування автотранспорту;

- низький рівень дотримання правил паркування;

- н низька дисципліна оплати паркувальних місць, відповідно до цього велика кількість коштів оминає бюджети міст;

- н недостатня обладнанність паркувальними автоматами, які б прозоро дозволяли здійснювати оплату за використану послугу;

- недостатня відповідальність при порушенні правил паркування.

Також слід зауважити, що на сьогоднішній день найбільшого поширення у м. Дніпро набули парковки, які займають крайню праву смугу руху. Таким чином, автомобілі, які стоять на проїзній частині, обмежують проїзд та відповідно суттєво зменшують пропускну здатність дороги і середню швидкість транспортного потоку, підвищують ймовірність виникнення дорожньо-транспортних пригод особливо у зоні перехресть. У зв'язку з цим було прийнято рішення проаналізувати вплив облаштування таких паркувальних місць на ефективність руху.

\section{ЦІЛЬ ТА ЗАДАЧІ ДОСЛІДЖЕННЯ}

Метою роботи $є$ отримання кількісної оцінки впливу облаштування паркувальних місць у крайній правій смузі на ефективність дорожнього руху на обраному об'єкті вулично-дорожньої мережі м. Дніпро. Для реалізації мети дослідження необхідно провести обстеження транспортних потоків; у програмному середовищі PTV VISSIM розробити імітаційні транспортні моделі перехрестя (без парковки та 3 парковкою); навести результати моделювання; обрати кількісні показників, за якими будуть порівнюватися обрані схеми транспортного руху; розрахувати значення комплексного критерію для оцінки ефективності руху; провести експертне оцінювання для визначення вагових коефіцієнти обраних показників ефективності ОДР.

\section{РЕЗУЛЬТАТИ ДОСЛІДЖЕНЬ}

У якості об'єкта дослідження було обрано перехрестя вул. Ярослава Мудрого та вул. Воскресєнської у м. Дніпро. Інтенсивності руху по смугам, а також світлофорні цикли на перехресті було визначені методом натурних обстежень. Світлофорні цикли перехрестя представлені на рисунках 2 та 3. Під час обстеження, яке проводилося у ранкову годину «пік» $38^{\underline{00}}$ до $9^{\underline{00}}$, інтенсивність руху по вул. Ярослава Мудрого становила 2208 авт./год., а по вул. Воскресєнська 1488 авт./год.

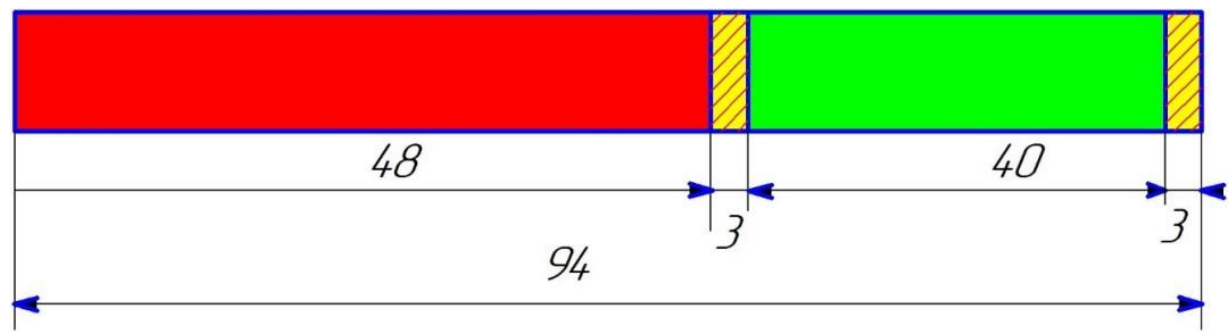

Рисунок 2 - Світлофорний цикл вулиці Воскресєнської

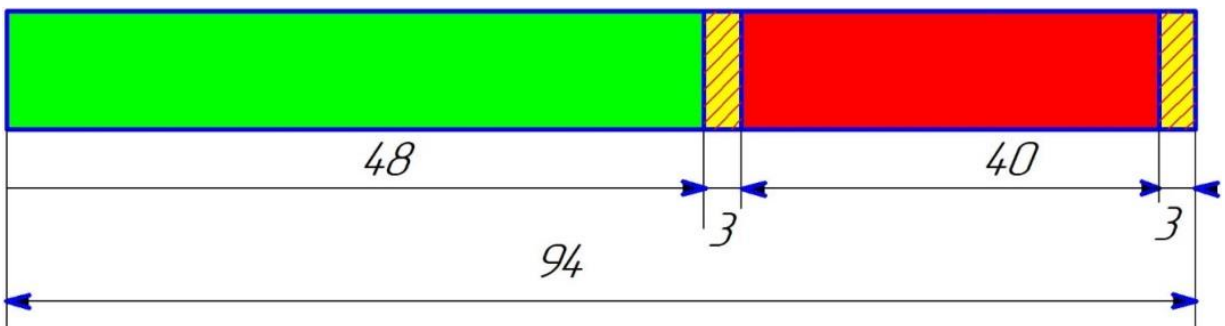

Рисунок 3 - Світлофорний цикл вулиці Ярослава Мудрого

У якості інструментарію моделювання був застосований програмний продукт PTV Vissim (64 bit) 11 «Студентська версія». Слід зауважити, що «Студентська версія» майже не має функціональних обмежень, але дозволяє досліджувати створені об'єкти лише протягом 600 с. Таким чином, отримані нижче результати моделювання є чинними для проміжку часу, який складає 10 хв. Враховуючи тривалість світлофорного циклу на перехресті вул. Воскресєнської - Ярослава Мудрого, який складає 94 с., автори вважають дане обмеження припустимим, а отримані результати мають право бути екстрапольовані спроектовані і на більш тривалі проміжки часу. 
У роботі [2] авторами був запропонований алгоритм створення моделі перехрестя у програмному середовищі PTV VISSIM. Згідно запропонованого алгоритму були розроблені дві імітаційні транспортні моделі перехрестя вул. Ярослава Мудрого та вул. Воскресєнської: без смуги та зі смугою для паркування (рисунки 4 та 5 відповідно).

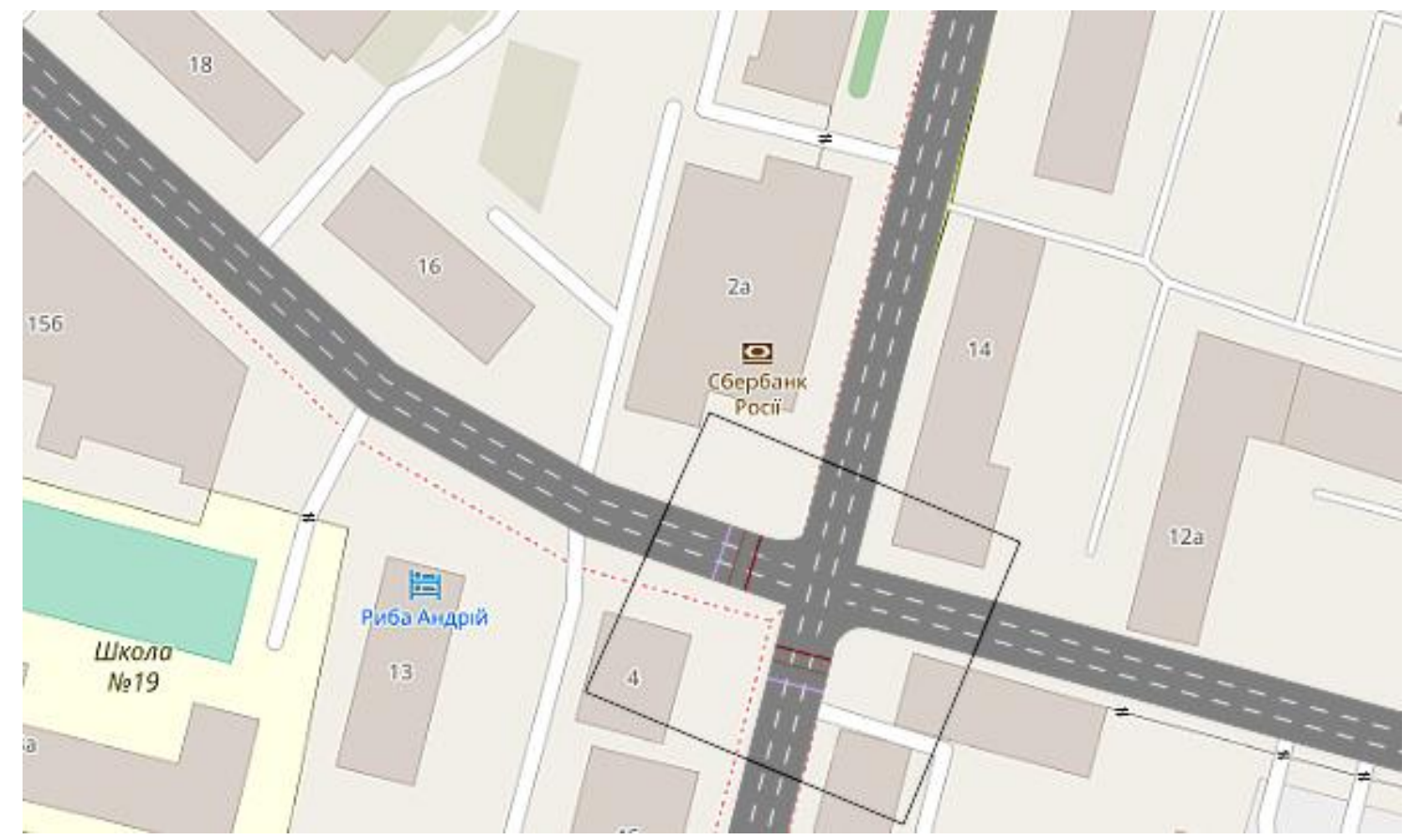

Рисунок 4 - Модель перехрестя вул. Ярослава Мудрого та вул. Воскресенська без смуги для паркування

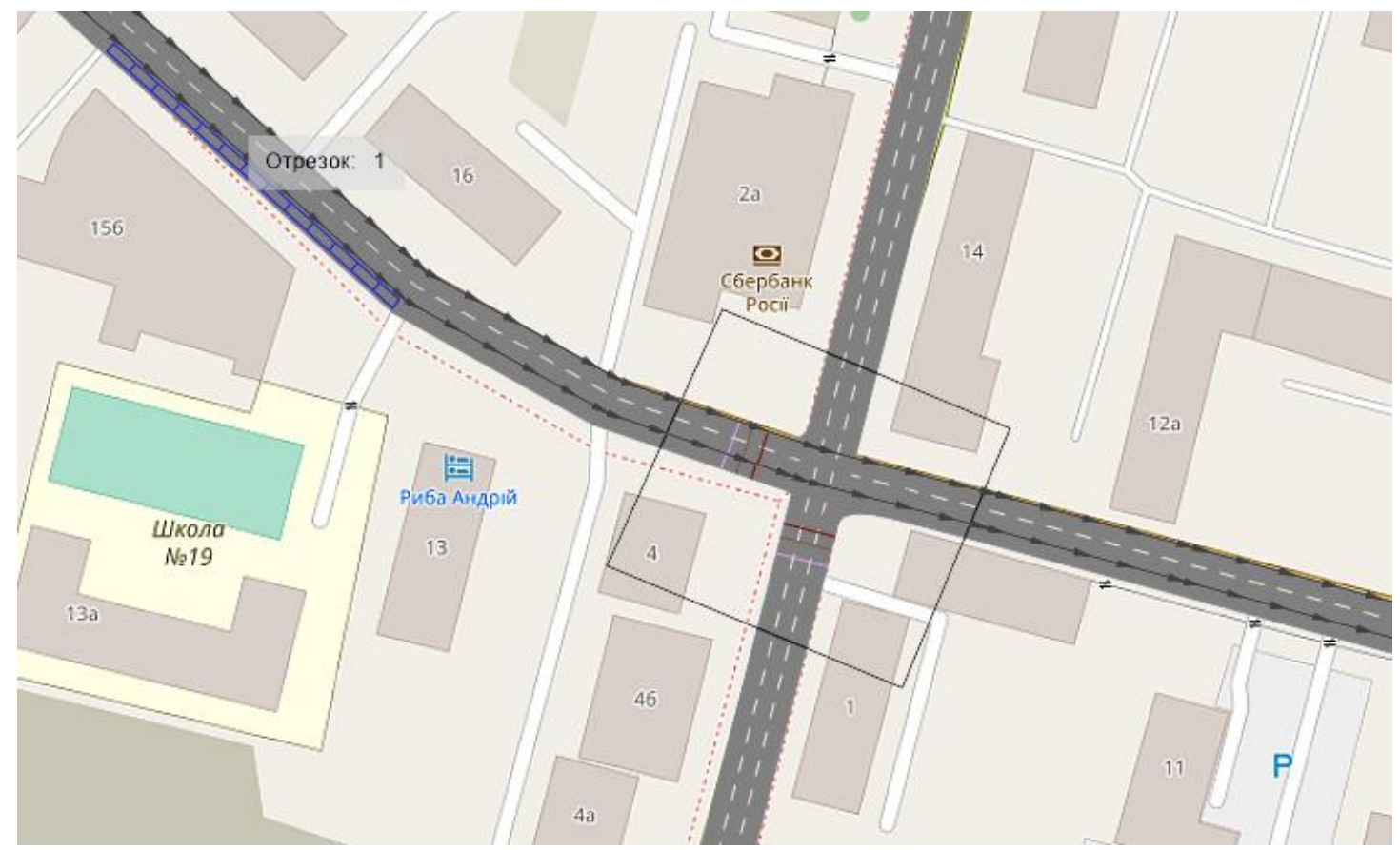

Рисунок 5 - Модель перехрестя вул. Ярослава Мудрого та вул. Воскресенська зі смугою для паркування

Фактично, облаштування паркування у крайній правій смузі руху, позбавляє ділянку дорогу однісї полоси, тому задача аналізу зводиться до порівняння дороги 3 трьома смугами та двома смугами руху. Процес імітації руху транспортних засобів для розроблених моделей наведений на рисунках 6 та 7. Навіть якісний аналіз процесу імітації дозволяє зробити висновок, що наявність смуги для паркування збільшує довжину затору і відповідно часу проїзду перехрестя. 


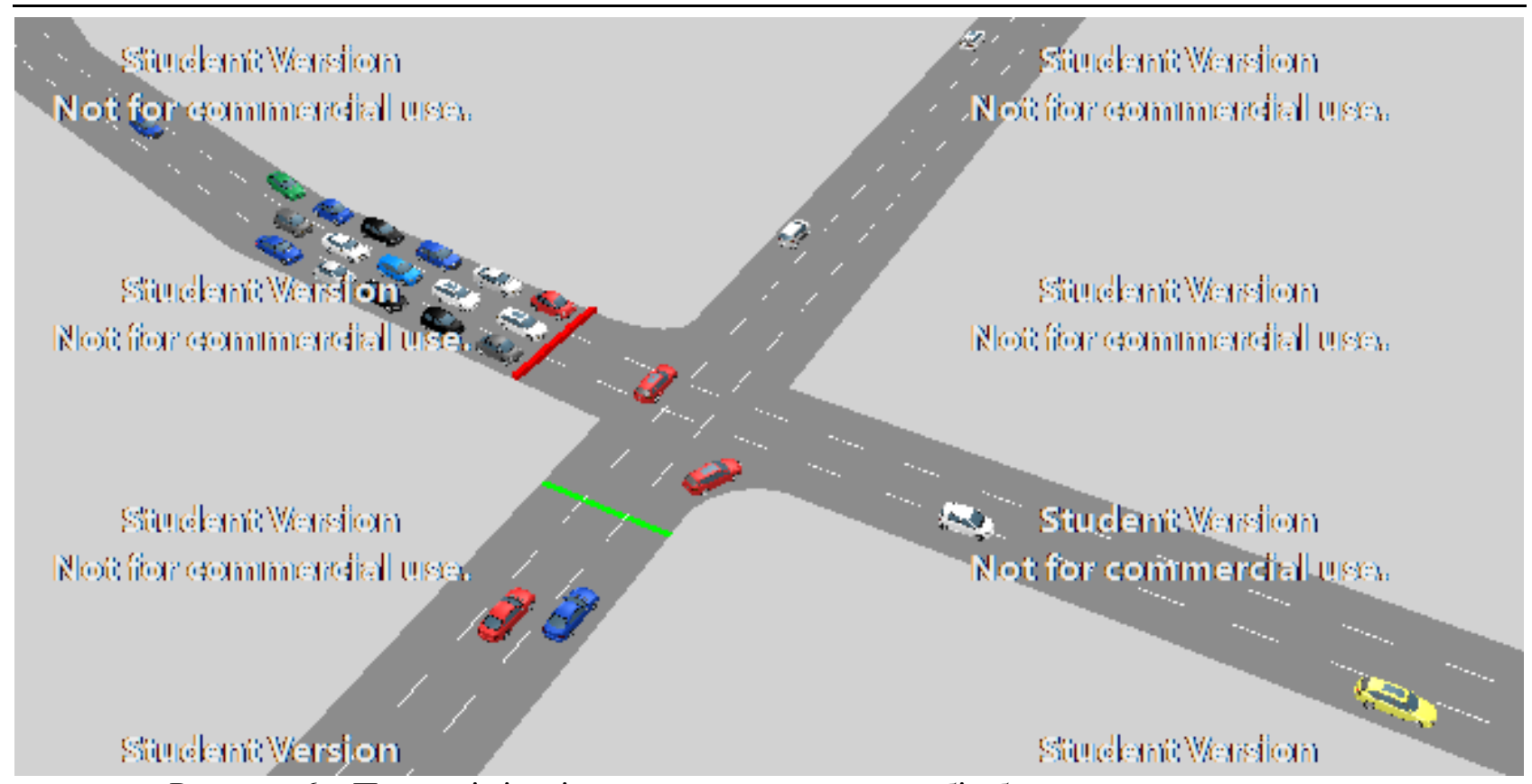

Рисунок 6 - Процес імітації руху транспортних засобів без смуги для паркування

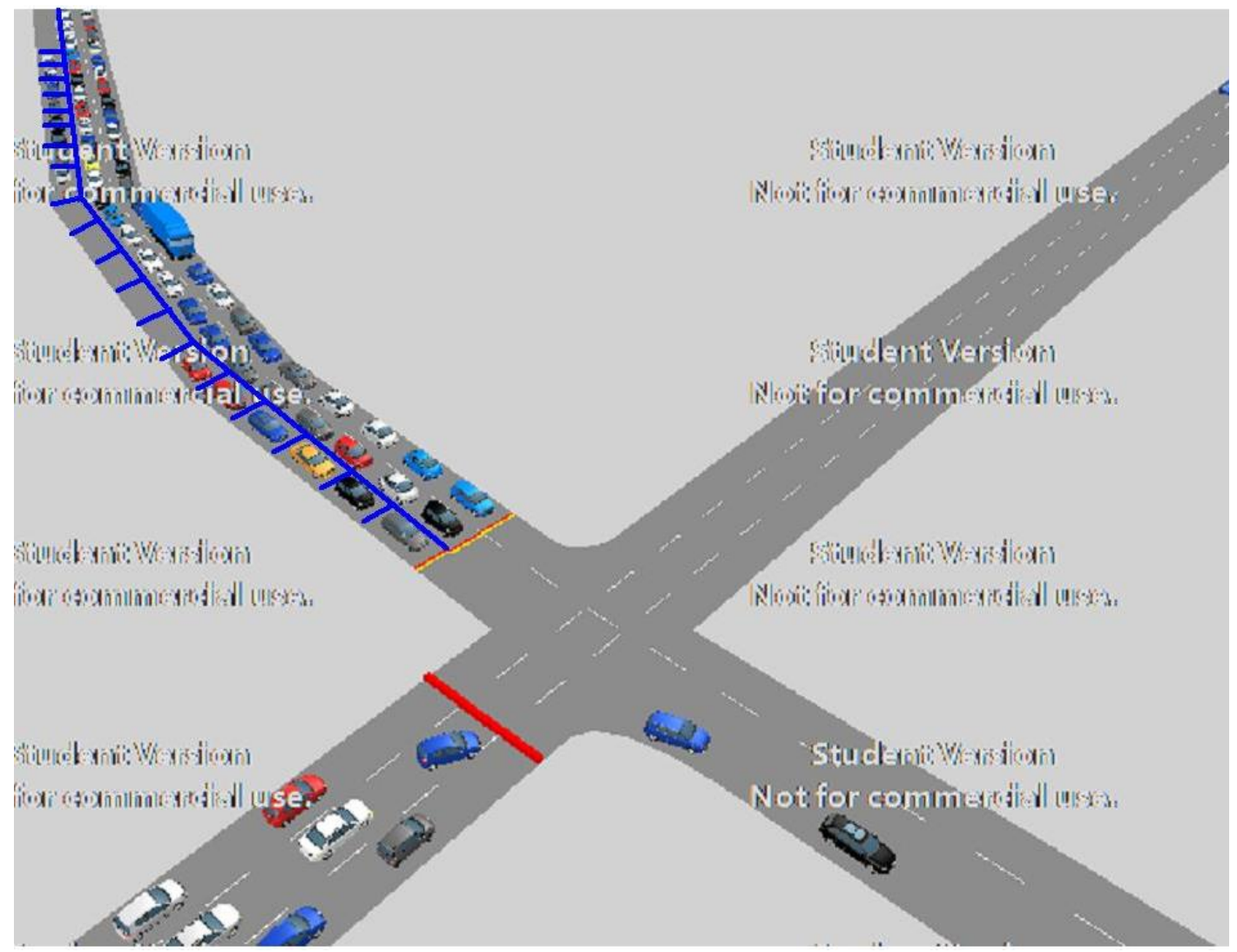

Рисунок 7 - Процес імітації руху транспортних засобів зі смугою для паркування

Згідно із рекомендаціями наданими у роботі [15] авторами був обраний перелік із 8 показників, які на їх думку є найбільш значущими для оцінки ефективності заходів з ОДР. Абсолютні (за результатами моделювання) обраних показників та розраховані за (6) їх відносні значення наведені у таблиці 1. 


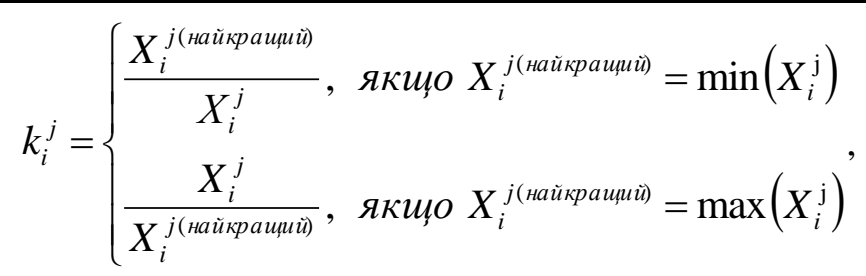
моделі.

де $X_{i}^{j}$ - абсолютне значення $j$-го показника $i$-го варіанту організації дорожнього руху

Таблиця 1 - Обрані для аналізу результати моделювання у PTV Vissim

\begin{tabular}{|c|c|c|c|c|c|c|}
\hline \multirow{3}{*}{$\begin{array}{l}\text { № } \\
\Pi / \Pi\end{array}$} & \multirow{3}{*}{ Показник } & \multicolumn{4}{|c|}{ Значення показників } & \multirow{3}{*}{ Ефект, \% } \\
\hline & & \multicolumn{2}{|c|}{ Без смуги для паркування } & \multicolumn{2}{|c|}{ Зі смугою для паркування } & \\
\hline & & абсолютне & відносне & абсолютне & відносне & \\
\hline 1 & $\begin{array}{l}\text { Середній час } \\
\text { затримки ТЗ, с }\end{array}$ & 6,5 & 1,00 & 14,49 & 0,45 & $-55 \%$ \\
\hline 2 & $\begin{array}{c}\text { Середня кількість } \\
\text { зупинок Т3, с } \\
\end{array}$ & 0,27 & 1,00 & 0,63 & 0,43 & $-57 \%$ \\
\hline 3 & $\begin{array}{c}\text { Середня швидкість, } \\
\text { км/год. }\end{array}$ & 30,9 & 1,00 & 19,42 & 0,63 & $-37 \%$ \\
\hline 4 & $\begin{array}{c}\text { Середній час } \\
\text { простою Т3, с }\end{array}$ & 14,68 & 1,00 & 31,69 & 0,46 & $-54 \%$ \\
\hline 5 & $\begin{array}{c}\text { Середній час у заторі } \\
\text { всіх Т3, с }\end{array}$ & 11,3 & 1,00 & 15,8 & 0,72 & $-28 \%$ \\
\hline 6 & $\begin{array}{c}\text { Середня довжина } \\
\text { затору, м } \\
\end{array}$ & 29,04 & 1,00 & 76,61 & 0,38 & $-62 \%$ \\
\hline 7 & Емісія СО, гр. & 491,97 & 1,00 & 714,41 & 0,69 & $-31 \%$ \\
\hline 8 & Витрати палива, л & 6,06 & 1,00 & 8,2 & 0,74 & $-26 \%$ \\
\hline
\end{tabular}

Для комплексної оцінки ефективності руху на окремому перехресті автори у роботі [16] запропонували використовувати функціонал наступного виду:

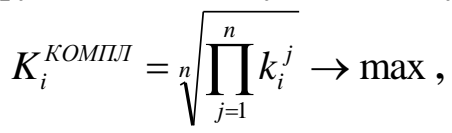

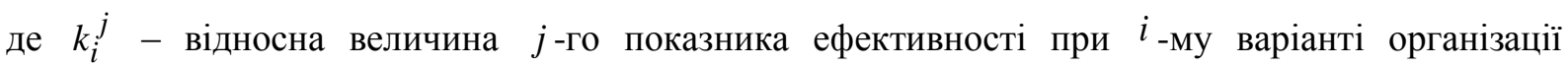
дорожнього руху; $n$ - кількість показників, що враховуються.

$$
\begin{gathered}
K_{3 \text { паркуваням }}^{\text {КОмП }}=\sqrt[8]{0,45 \cdot 0,43 \cdot 0,63 \cdot 0,46 \cdot 0,72 \cdot 0,38 \cdot 0,69 \cdot 0,74}=0,54 . \\
K_{\text {без паркувиня }}^{\text {КОмП }}=\sqrt[8]{1,00 \cdot 1,00 \cdot 1,00 \cdot 1,00 \cdot 1,00 \cdot 1,00 \cdot 1,00 \cdot 1,00}=1,00 .
\end{gathered}
$$

Радарна діаграма відносних показників та загальна характеристика ефективності облаштування паркувальних місць у крайній правій смузі руху наведена на рисунках 8 та 9 відповідною. Значення запропонованого комплексного показника ефективності (7) для дороги без паркувальних місць становить $-1,00$, а для дороги 3 місцями - 0,54, таким чином загальна ефективність такого рішення для обраного об'єкту дослідження знизила ефективність ОДР на 46\%. 


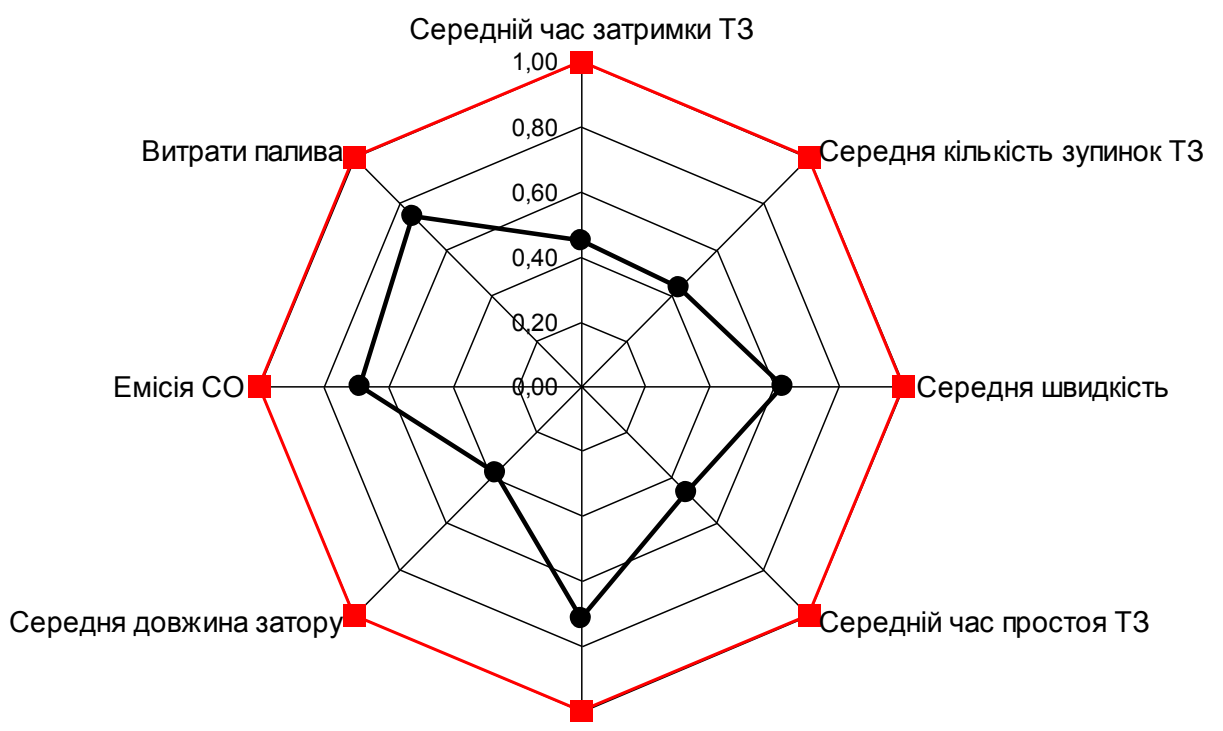

Середній час у заторі всіх Т3

- Без смуги для паркування

Зі смугою для паркування

Рисунок 8 - Радарна діаграма відносних величин показників ефективності ОДР

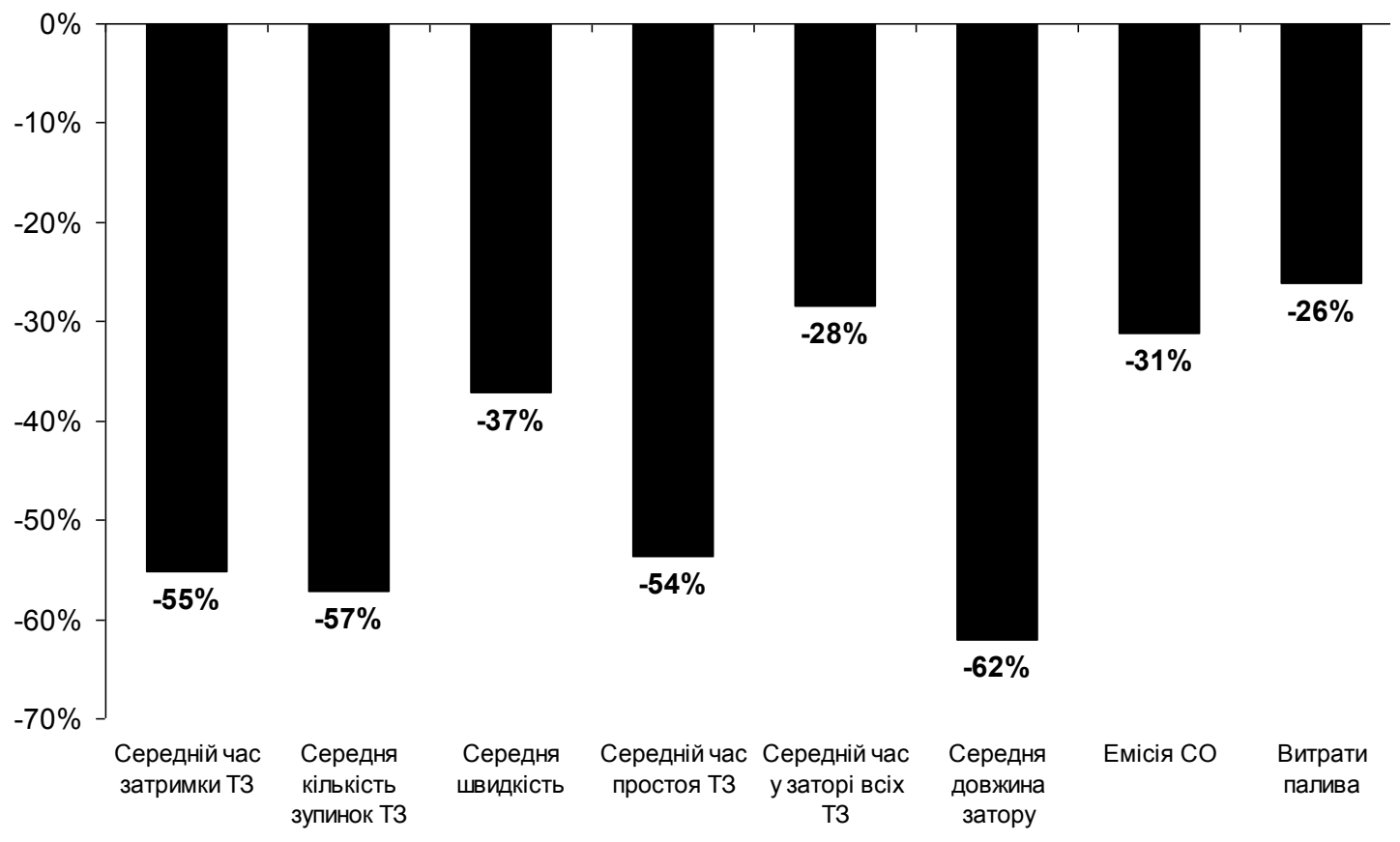

Рисунок 9 - Оцінка ефективності влаштування паркування на крайній правій смузі руху

Авторами було зроблено припущення, що обрані показники ефективності (таблиця 1) можуть мати нерівномірну значущість під час прийняття остаточних рішень щодо вибору варіанту організації дорожнього руху. Таким чином виникає необхідність у їх ранжуванні та визначенні вагових коефіцієнтів $\omega^{j}$. За умови $\sum_{j=1}^{n} \omega^{j}=1$ остаточна структура запропонованого критерію набуде наступного виду:

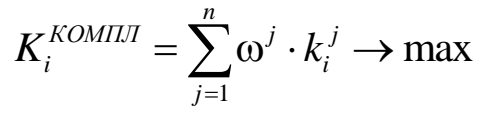

де $\omega^{j}$ - ваговий коефіцієнт $j$-го показника ефективності.

Для визначення числових значень $\omega^{j}$ було прийнято рішення залучити «експертів» спеціалістів, які мають практичний досвід вирішення задач з ОДР та створенні транспортних моделей 
у середовище VISSIM. Розроблений для експертного оцінювання бланк опитування наведений на рисунку 10.

Прізвище, ім'я та по батькові:

Назва установи:

Вчене звання:

Посада:

\begin{tabular}{|l|l|l|l|l|}
\hline \multicolumn{1}{|c|}{ Назва функції у PTV VISSIM } & \multicolumn{1}{|c|}{ 3міст функції } & \multicolumn{1}{|c|}{$\begin{array}{c}\text { ПРІАРІTЕT (число від } 1 \text { до 8 } \\
\text { у порядку зменьшення } \\
\text { значимості показника }\end{array}$} \\
\hline Час затримки (середнє значення) & Середній час затримки Т3 & & \\
\hline Зупинки (середнє значення) & Середня кількість зупинок Т3 & & \\
\hline Швидкість (середня) & Середня швидкість & & \\
\hline Час простою & Середній час простою Т3 & & \\
\hline Час в заторі & Час в заторі всіх Т3 & & \\
\hline Довжина затору (середня) & Середня довжина затору & & \\
\hline Емісія СО & Кількість монооксида вуглецю на 1 Т3 & & \\
\hline Витрати палива & Витрати палива & & \\
\hline
\end{tabular}

Рисунок 10 - Бланк опитування для експертного оцінювання

Всього в оцінюванні прийняло участь 14 фахівців - викладачів кафедр (із 7 ВНЗ України) за спеціальністю 275 Транспортні технології (на автомобільному транспорті), з них 12 мають вчене звання, в т.ч. 6 докторів технічних наук та 5 завідуючих кафедрою. Автори виражають велику вдячність усім фахівцям, які прийняли учать у запропонованому експертному оцінюванні. Результати оцінювання наведені у таблиці 2, а на рисунку 11 представлені результати розрахунку вагових коефіцієнтів $\omega^{j}$.

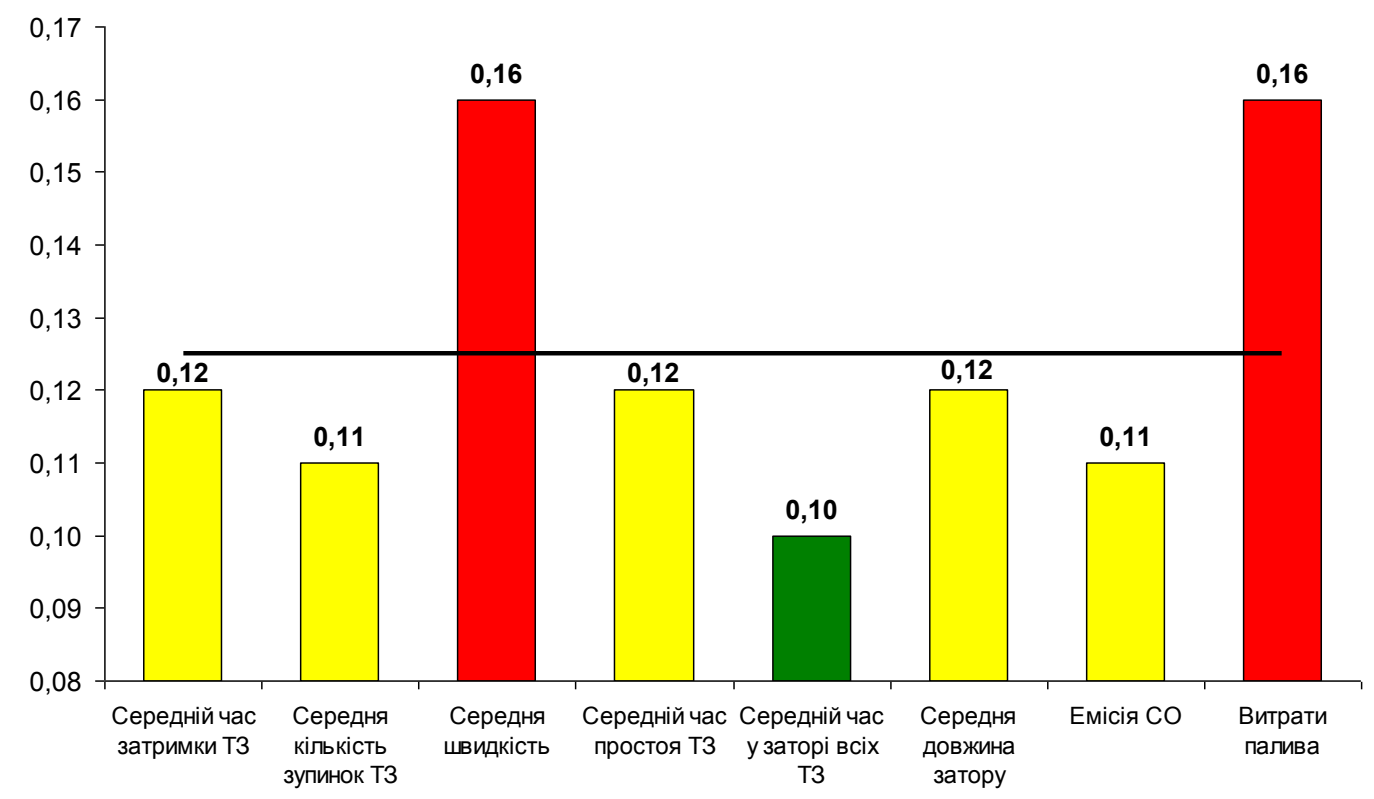

Рисунок 11 - Значення вагових коефіцієнтів обраних показників ефективності 
荡

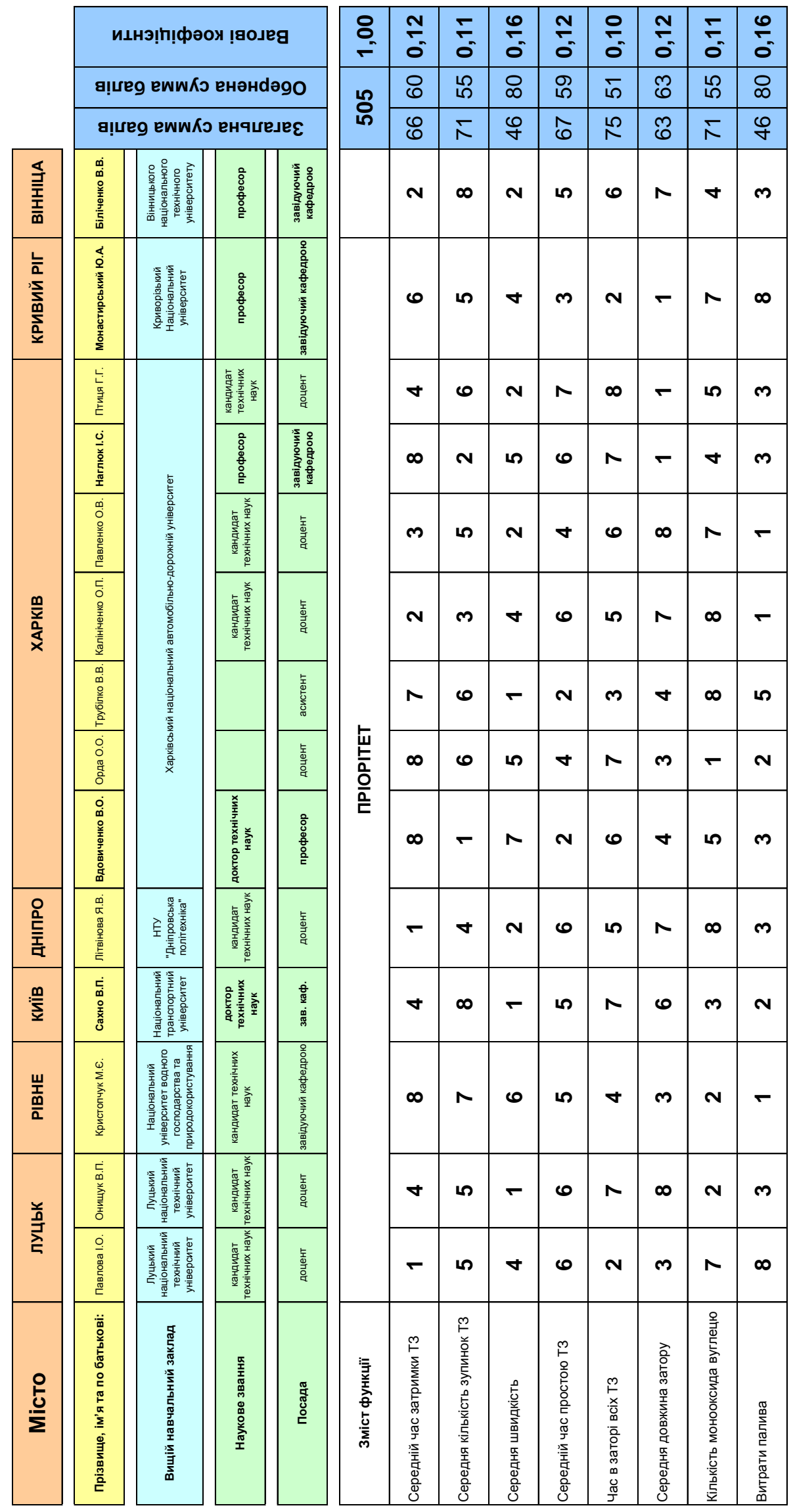

Аналіз рисунку 11 свідчить, що розподіл вагових коефіцієнтів $\omega^{j}$ характеризується дуже незначною розбіжністю: при середньому значенні $\bar{\omega}=0,125$ дисперсія вибірки становить 0,0005 , а 
довірчий інтервал для математичного очікування генеральної сукупності при 95\% рівні надійності 0,0157. Отримані результати дозволяють зробити наступні висновки. По-перше, всі обрані авторами показники $€$ значимими під час прийняття остаточних рішень щодо обгрунтування заходів 3 підвищення ефективності дорожнього руху. По-друге, враховуючи незначну розбіжність вагових коефіцієнтів підсумкове значення комплексного критерію за (8) не буде суттєво відрізнятися від значення, яке було розраховано за (7):

$$
\begin{gathered}
K_{\text {з паркуваням }}^{\text {КОМП }}=0,12 \cdot 0,45+0,11 \cdot 0,43+0,16 \cdot 0,63+0,12 \cdot 0,46+ \\
+0,1 \cdot 0,72+0,12 \cdot 0,38+0,11 \cdot 0,69+0,16 \cdot 0,74=0,53 \\
K_{\text {без паркувниня }}^{\text {КОМП }}=1,00 .
\end{gathered}
$$

\section{ОБГОВОРЕННЯ РЕЗУЛЬТАТІВ ДОСЛІДЖЕННЯ}

Результати досліджень обговорювались на VI Міжнародній науково-технічній конференції «Науково-прикладні аспекти автомобільної і транспортно-дорожньої галузей», місто Луцьк, Луцький Національний технічний університет, 26-27 травня 2020 року.

\section{ВИСНОВКИ}

Стрімкі темпи росту автомобілізації призвели до значного перевищення попиту на місця паркування над наданою їх кількістю. Подібна ситуація є характерною рисою більшості середніх та великих міст України. В умовах недоліку місць для паркування найбільшого поширення набуло облаштування паркувальних місць у крайній правій смузі. Застосування даного заходу призводе до зниження пропускної спроможності вулично-дорожньої мережі міста та погіршення умов безпеки руху транспорту. Було прийнято рішення проаналізувати вплив облаштування таких паркувальних місць на ефективність руху в умовах мі. Дніпро. У якості об'єкта дослідження було обрано перехрестя вул. Ярослава Мудрого та вул. Воскресєнської. Інтенсивності руху по смугам, а також світлофорні цикли на перехресті було визначені методом натурних обстежень. Розроблені дві імітаційні транспортні моделі перехрестя (без смуги та зі смугою для паркування) у програмному середовищі PTV VISSIM. Результати моделювання, засвідчують, що облаштування паркувальних місць у крайній правій смузі знижує ефективності руху за всіма обраними показниками в діапазоні від $26 \%$ до $62 \%$. Значення запропонованого авторами комплексного показника ефективності для дороги без парковки становить - 1,00, а для дороги 3 парковкою - 0,54, таким чином загальна ефективність такого рішення для обраного об'єкту дослідження знизила ефективність ОДР на 46\%. Проведено експертне оцінювання за результатами якого були розраховані вагові коефіцієнти для обраних показників ефективності ОДР.

\section{ПЕРЕЛІК ДЖЕРЕЛ ПОСИЛАННЯ}

1. Організація та регулювання дорожнього руху: підручник / Бакуліч О.О. та ін.; за ред. В.П. Поліщука. Київ. 2016. 467 с.

2. Таран И.А., Новицкий А.В., Литвин В.В. Анализ возможностей использования программного обеспечения PTV VISION VISSIM для моделирования транспортных и пешеходных потоков. Вісник СНУ ім. В. Даля. 2015. №2 (219). с. 136-140.

3. Транспортне планування міст. Поліщук В.П., Красильникова О.В., Дзюба О.П.; за ред. В.П. Поліщука. Київ. 2014. 371 с.

4. Системологія на транспорті. Організація дорожнього руху. Гаврилов Е.В. та ін.; за ред. М.Ф. Дмитриченка. Київ. 2007. 452 с.

5. Галкина Н. Г. Исследование городских парковок. Вестник ХНАДУ. 2010. № 50. с. 84-87.

6. Швець В.В., Іскра М.А., Кудлаєнко О.О. Планування підземних парковок в умовах щільної міської забудови. Сучасні технології, матеріали і конструкцї в будівнищтві. 2013. № 1. с. 108-112.

7. Чернышев С.А., Петров А.В. К вопросу об оптимизации систем автопарковки в условиях современного города. Вестник Донеикой академии автомобильного транспорта. 2008. № 4. с. 18-22.

8. Патракеев И.М., Жуков В.Е. Леонтьева О.Г. Организация парковок в крупном городе на основе пространственно-точного моделирования. Ученые записки Крымского федерального университета имени В.И. Вернадского. 2010. №2. с. 222-231.

9. Armstrong D. \& Rhoades B. (2015). Parking spaces. Advances in Mathematics. \#269. 647-706. 
10. Molenda I. \& Sieg G. (2013) Residential parking in vibrant city districts. Economics of Transportation. Vol.2. \#4. 131-139.

11. Roca-Riu M. \& Fernández E. \& Estrada M. (2015). Parking slot assignment for urban distribution: Models and formulations. Omega. \#57. Part B. 157-175.

12. Van Ommeren J. \& De Groote J. \& Mingardo G. (2014). Residential parking permits and parking supply. Regional Science and Urban Economics. \#45. 33-44.

13. Xiong Lu. (2014). Innovative design of parking guidance in intelligent parking lot. Innovation and Sustainability of Modern Railway. \#2. 128-133.

14. Zheng N. \& Geroliminis N. (2016). Modeling and optimization of multimodal urban networks with limited parking and dynamic pricing. Transportation Research Part B: Methodological. \#83. 36-58.

15. Управління дорожнім рухом на регульованих перехрестях у містах: монографія / Форнальчик Є.Ю., Могила І.А., Трушевський В.Е., Гілевич В.В.; за ред. С. Ю. Форнальчика. Львів. 2018. $236 \mathrm{c}$.

16. Литвин В.В., Таран І.О., Кононенко К.С. Обгрунтування ефективності застосування кільцевого руху на вулично-дорожній мережі м. Дніпро у програмному середовищі PTV VISSIM. Сучасні технології в машинобудуванні та транспорті. 2019. №2 (13). с. 95-107.

\section{REFERENCES}

1. Organizacziya ta regulyuvannya dorozhnogo rukhu: pidruchnik (2016). Bakulich O.O. ta in.; za red. V.P. Polishhuka. 467.

2. Taran I.A., \& Noviczkij A.V., \& Litvin V.V. (2015). Analiz vozmozhnostej ispolzovaniya programmnogo obespecheniya PTV VISION VISSIM dlya modelirovaniya transportnykh i peshekhodnykh potokov. Visnik SNU im. V. Dalya. \#2 (219). 136-140.

3. Transportne planuvannya mist (2014). Polishhuk V.P., Krasilnikova O.V., Dzyuba O.P.; za red. V.P. Polishhuka. 371.

4. Sistemologiya na transporti. Organizacziya dorozhnogo rukhu (2007). Gavrilov E.V. ta in.; za red. M.F. Dmitrichenka. 452.

5. Galkina N. G. (2010). Issledovanie gorodskikh parkovok. Vestnik KhNADU. \# 50. 84-87.

6. Shvecz V.V. \& Iskra M.A. \& Kudlayenko O.O. (2013). Planuvannya pidzemnikh parkovok v umovakh shhilnoyi miskoyi zabudovi. Suchasni tekhnologiyi, materiali i konstrukcziyi v budivnicztvi. \#1. 108-112.

7. Chernyshev S.A. \& Petrov A.V. (2008). K voprosu ob optimizaczii sistem avtoparkovki v usloviyakh sovremennogo goroda. Vestnik Doneczkoj akademii avtomobil nogo transporta. \# 4. 18-22.

8. Patrakeev I.M. \& Zhukov V.E. \& Leonteva O.G. (2010). Organizacziya parkovok v krupnom gorode na osnove prostranstvenno-tochnogo modelirovaniya. Uchenye zapiski Krymskogo federalnogo universiteta im. V.I. Vernadskogo. \#2. 222-231.

9. Armstrong D. \& Rhoades B. (2015). Parking spaces. Advances in Mathematics. \#269. 647-706.

10. Molenda I. \& Sieg G. (2013) Residential parking in vibrant city districts. Economics of Transportation. Vol.2. \#4. 131-139.

11. Roca-Riu M. \& Fernández E. \& Estrada M. (2015). Parking slot assignment for urban distribution: Models and formulations. Omega. \#57. Part B. 157-175.

12. Van Ommeren J. \& De Groote J. \& Mingardo G. (2014). Residential parking permits and parking supply. Regional Science and Urban Economics. \#45. 33-44.

13. Xiong Lu. (2014). Innovative design of parking guidance in intelligent parking lot. Innovation and Sustainability of Modern Railway. \#2. 128-133.

14. Zheng N. \& Geroliminis N. (2016). Modeling and optimization of multimodal urban networks with limited parking and dynamic pricing. Transportation Research Part B: Methodological. \#83. 36-58.

15. Fornalchik Ye.Yu., \& Mogila I.A., \& Trushevskij V.E., \& Gilevich V.V. (2018). Upravlinnya dorozhnim rukhom na regulovanikh perekhrestyakh u mistakh: monografiya. 236.

16. Litvin V.V. \& Taran I.O. \& Kononenko K.S. (2019). Obgruntuvannya efektivnosti zastosuvannya kilczevogo rukhu na vulichno-dorozhnij merezhi m. Dnipro u programnomu seredovishhi PTV VISSIM. Suchasni tekhnologiyi v mashinobuduvanni ta transporti. 2019. \#2 (13). 95-107. 


\begin{abstract}
V. Litvin., I. Taran. Quantative evaluation of effect by arrangement of parking spaces within a right line on the traffic efficiency

Rapid growth of motorization resulted in the excess demand for parking spaces over their quantity. Such a situation is typical for the majority of Ukrainian cities and towns. In the context of shortage of parking spaces, their arrangement within a right line has become quite popular. The measure factors into the decreased capacity of road network as well as the worsened traffic safety conditions. Thus, the paper has analyzed effect of arrangement of such parking places on the traffic efficiency in the city of Dnipro. Ya. Mudry-Voskresenska crossroad has been selected as the test object. Intensity of traffic flows within the crossroad was obtained using a method of field studies for a morning rush hour from 7 a.m. to 8 a.m. Two simulation traffic models of the crossroad (i.e. without a parking lane and with it) have been developed in PTV VISSIM software environment. The modeling results support the idea that arrangement of parking spaces within a right line decreases traffic efficiency by $26-62 \%$ in terms of each selected index. The authors have proposed the complex efficiency index. It is 1.00 for road without parking places; and 0.54 for road where parking lanes have been arranged. It has been proved that the total efficiency of such a solution for the selected test object decreased traffic management by $46 \%$. Expert evaluation has been performed to calculate weight coefficients for the selected indices. The obtained distribution of the weight coefficients is characterized by a minor discrepancy. The abovementioned means that the indices, selected by the authors, are quite important while making final decisions as for the substantiation of measures improving traffic efficiency.
\end{abstract}

Keywords: street and road network, traffic lane, crossroad, simulation modeling, traffic jam length, weight coefficients, delay time, traffic, PTV VISSIM.

ЛИТВИН Вадим Вікторович, старший викладач кафедри «Управління на транспорті», Національний технічний університет «Дніпровська політехніка», e-mail: litvin.v.v.79@gmail.com. http://orcid.org/0000-0002-1572-9000.

ТАРАН Ігор Олександрович, доктор технічних наук, професор, завідувач кафедри «Управління на транспорті», Національний технічний університет «Дніпровська політехніка», e-mail: taran7077@gmail.com. http://orcid.org/0000-0002-3679-2519.

Vadim LITVIN, senior lecturer of Transport Management Department, National Technical University “Dnipro Polytechnic", e-mail: litvin.v.v.79@ gmail.com. http://orcid.org/0000-0002-1572-9000.

Igor TARAN, Doctor of Science in Technology, Professor, Head of Transport Management Department, National Technical University "Dnipro Polytechnic", e-mail: taran7077@gmail.com. http://orcid.org/0000-0002-3679-2519.

DOI: 10.36910/automash.v2i15.391 